\title{
FAKTOR- FAKTOR YANG MEMPENGARUHI MOTIVASI WANITA BEKERJA SEBAGAI BURUH PABRIK GARMEN DI PT AMEYA LIVING STYLE INDONESIA
}

\author{
Wantini dan Kurniati \\ (Prodi Ekonomi Syariah Sekolah Tinggi Ilmu Agama Alma Ata)
}

\begin{abstract}
This study aims to identify how the effect of economic motives and religious motives that influence the motivation of women to work as a garment factory worker. Penganbilan in this study used a sample of 50 respondents, data collection techniques with the use of questionnaires, and research variables are economic motives (X1), religious motives (X2), and the motivation of women to work as factory worker (Y).

Data validity was tested using the Pearson product moment correlation, and to mengujitingkat Cronbach alpha reliability using, then the data is processed by Multiple Linear Regression Analysis. Hypothesis testing using $t$ test and $F$ test with a significance level of 5\%. This research uses tools SPSS version 13.

These results indicate that there is significant influence of each variable on the motivation of women to work as factory workers.

Keywords: Women, motivation, worker

\section{A. Pendahuluan}

Indonesia merupakan negara berkembang sehingga banyak pembangunan dimana-mana dan industri merupakan suatu akibat karena adanya pembangunan. Dengan adanya pembangunan diharapkan dapat meningkatkan potensi sumberdaya nasional yang kemudian dapat diarahkan menjadi kekuatan ekonomi, politik, dan pertahanan nasional. Sumberdaya manusia seperti wanita merupakan salah satu penggerak pembangunan nasional dengan diiringi kreatifitas, aspirasi, dan melalui peranan aktifnya dalam segala pembangunan. Contohnya dengan adanya sektor industri maka banyak pula tenaga kerja wanita yang digunakan untuk menjadikan industri tersebut menjadi maju dan berkembang, ini merupakan suatu wujud asli peran suberdaya manusia dalam kegiatan pembangunan nasional.( Mugnesiah, 1986)

Fenomena wanita bekerja sebenarnya sudah tidak asing lagi kita dengar dan perhatikan di masyarakat kita. Bahkan sejak dulu wanita sudah bekerja dari buruh tani, pedagang, buruh pabrik, buruh kerajinan dan lain
\end{abstract}


sebagainya. Ada dua motif yang menjadikan wanita bekerja yaitu motif ekonomi dan motif religiusitas. Kalau dilihat dari motif religiusitas atau agama tujuan wanita bekerja karena untuk mendapatkan pahala dari Allah SWT, bekerja merupakan suatu ibadah yaitu meringankan beban suami dalam mencari nafkah untuk memenuhi kebutuhan hidup atau bagi yang belum berkeluarga bekerja adalah ibadah karena merupakan suatu pengabdian dan berbakti kepada orang tua, seperti dalam firman Allah SWT di bawah ini:

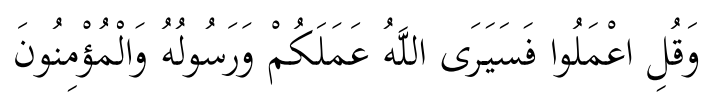

Artinya: "Katakanlah (wahai Muhammad), bekerjalah kalian! maka Allah, Rasul-Nya, dan para mukminin akan melihat pekerjaanmu" (QS. AtTaubah:105)

Ada hal-hal yang perlu diperhatikan, jika wanita ingin bekerja, diantaranya:

a. Pekerjaannya tidak mengganggu kewajiban utamanya dalam urusan dalam rumah, karena mengurus rumah adalah pekerjaan wajibnya, sedang pekerjaan luarnya bukan kewajiban baginya, dan sesuatu yang wajib tidak boleh dikalahkan oleh sesuatu yang tidak wajib.

b. Harus dengan izin suaminya, karena istri wajib mentaati suaminya.

c. Menerapkan adab-adab islami, seperti: Menjaga pandangan, memakai hijab syar'i, tidak memakai wewangian, tidak melembutkan suaranya kepada pria yang bukan mahrom.

d. Pekerjaannya sesuai dengan tabi'at wanita,misalnya mencari ilmu pengetahuan.

e. Tidak ada ikhtilat di lingkungan kerjanya. Hendaklah ia mencari lingkungan kerja yang khusus wanita, misalnya: Sekolah wanita, perkumpulan wanita, kursus wanita.

f. Hendaklah mencari dulu pekerjaan yang bisa dikerjakan di dalam rumah. Jika tidak ada, baru cari pekerjaan luar rumah yang khusus di kalangan wanita. Jika tidak ada, maka ia tidak boleh cari pekerjaan luar rumah yang campur antara pria dan wanita, kecuali jika keadaannya darurat atau keadaan sangat mendesak sekali, misalnya suami tidak mampu mencukupi kehidupan keluarganya, atau suaminya sakit. (Addariny, 2013)

Kalau dilihat dari motif ekonomi bekerja hanya untuk mendapatkan uang agar dapat memenuhi kebutuhan hidupnya, dan hanya kebutuhan lahiriah saja yang menjadi tujuannya. Akan tetapi apabila kedua motif yaitu motif ekonomi dan motif religius dapat dipenuhi keduanya menjadi kesempurnaan manusia dalam memenuhi kebutuhan hidupnya. Motivasi wanita-wanita di dusun Gupakwarak untuk bekerja dikarenakan kondisi ekonomi yang kurang untuk memenuhi kebutuhan hidupnya, ingin menambah penghasilan keluarga dengan ijin suami, tempat bekerja lebih dekat dengan gaji lebih besar dibandingkan bekerja sebagai buruh tani atau buruh kerajinan.

Karena di dusun Gupakwarak merupakan tempat berdirinya industri pabrik garmen dan banyak wanita-wanita karir yang bekerja sebagai buruh pabrik tersebut maka penulis ingin menilik lebih dalam lagi terhadap faktor-faktor yang mempengaruhi motivasi wanita di dusun

Wantini 
Gupakwarak ini bekerja sebagai buruh pabrik garmen di PT Ameya Living Style Indoneesia. Berdasarkan latar belakang yang penulis paparkan, maka penulis tertarik untuk meneliti lebih jauh tentang Faktor-Faktor Yang Mempengaruhi Motivasi Wanita Bekerja Sebagai Buruh Pabrik Garmen Di PT Ameya Living Style Indonesia dengan studi kasus di dusun Gupakwarak Sendangsari Pajangan Bantul.

\section{B. Rumusan Masalah}

Berdasarkan pemaparan dari latar belakang di atas maka pokok permasalahan yang akan dikaji adalah: Faktor-faktor apa saja yang mempengaruhi motivasi wanita bekerja sebagai buruh pabrik garmen di PT Ameya Living Style Indonesia.

\section{Tujuan Penelitian}

Berdasarkan perumusan permasalahan di atas, maka tujuan penelitian ini yang hendak dicapai adalah: Untuk mengetahui faktor-faktor yang mempengaruhi motivasi wanita bekerja sebagai buruh pabrik garmen di PT Ameya Living Style Indonesia

\section{Manfaat Penelitian}

Manfaat dari penelitian ini adalah dapat memberikan masukan untuk menambah dan memotivasi karyawan-karyawannya untuk bekerja lebih baik lagi, memberikan sumbangan pemikiran tentang motivasi wanita bekerja dan sebagai dasar untuk mengembangkan ilmu pengetahuan ekonomi, menambah khasanah pengalaman dan pengetahuan bagi peneliti tentang motivasi wanita bekerja.

\section{E. Landasan Teori}

Motivasi adalah kekuatan yang mendorong seseorang karyawan untuk menimbulkan dan mengarahkan perilaku individu. Sehingga semakin besar motivasi yang dimiliki oleh individu sebagai karyawan dapat meningkatkan prestasi kerja yang lebih baik. Salah satu bentuk motivasi kerja adalah faktor-faktor yang ada dalam diri seseorang yang menggerakkan dan mengarahkan perilakunya untuk memenuhi tujuan tertentu. (Robbins, 2002) Kebutuhan manusia dirinci ke dalam tujuh tingkat kebutuhan, yaitu:

a. Kebutuhan Dasar Fisiologis, adalah kebutuhan untuk mempertahankan hidupnya secara fisik, yaitu kebutuhan akan makanan, minuman, tempat berteduh, seks, tidur, dan oksigen.

b. Kebutuhan akan Rasa Aman, adalah kebutuhan yang mendorong individu untuk memperoleh ketentraman, kepastian, dan keraturan dari

Faktorkeadaan lingkungannya. Misalnya usaha-untuk memperoleh perlindungan dan keselamatan kerja, membayar asuransi.

faktor

c. Kebutuhan akan Kasih Sayang, adalah kebutuhan yang mendorong individu untuk mengadakan hubungan afektif atau ikatan emosional dengan individu lain, baik dengan sesama jenis maupun dengan yang berlainan jenis, di lingkungan keluarga maupun di lingkungan kelompok masyarakat. 
d. Kebutuhan akan Penghargaan, Penghargaan dari orang lain meliputi prestasi, pengakuan, penerimaan, perhatian, kedudukan, nama baik serta penghargaan.

e. Kebutuhan Ilmu Pengetahuan, Maslow berkeyakinan bahwa salah satu ciri mental yang sehat ialah adanya rasa ingin tahu.

f. Kebutuhan Estetika yaitu kebutuhan akan keindahan

g. Kebutuhan Aktualisasi Diri, aktualisasi diri dapat didefinisikan sebagai perkembangan yang paling tinggi dan penggunaan semua bakat kita, pemenuhan semua kualitas dan kapasitas kita. (Duane, 1991)

Motivasi sangat dibutuhkan untuk mencapai suatu tujuan seseorang, tanpa adanya motivasi seseorang akan merasa tidak semangat untuk melakukan segala kegiatannya. Dari sudut motivasi tinjauan wanita bekerja dapat dikelompokkan menjadi dua kelompok yaitu kelompok pertama, wanita bekerja karena kebutuhan ekonomi yang kedua wanita bekerja bukan semata-mata hanya alasan ekonomi akan tetapi karena alasan lainnya misalnya alasan agama dengan makna bahwa bekerja adalah ibadah. Bagi kelompok pertama, mengharapkan agar pembangunan dapat lebih banyak memberikan lapangan pekerjaan bagi kaumnya, agar dapat lebih mudah untuk meningkatkan pendapatan keluarga. Bagi kelompok kedua selain mendapatkan pahala, kemudahan lapangan pekerjaan, juga mendapatkan penyaluran persamaan hak dalam segala pembangunan.

Di dalam sistem industri, buruh adalah suatu tenaga penggerak produksi yang memiliki kekhususan tersendiri yang tidak dapat disamakan dengan unsur-unsur lainnya dalam proses produksi. Buruh adalah satu-satunya unsur yang ada di dalam produksi yang mempunyai tujuan kehendak dan sadar dapat menahan pekerjaan dan meningkatkannya. Pengertian buruh berarti pekerja yaitu mereka yang bekerja dengan menggunakan tenaga kerja kasar kemudian memperoleh imbalan berupa gaji atau upah. Pengertian ini ditujukan pada pekerja yang melakukan kerja berat, yang mengandalkan kekuatan fisik, tidak memiliki ketrampilan, khusus untuk wanita walaupun mereka tidak mengandalkan kekuatan fisik, tetapi mengandalkan ketelitian, kesabaran, dan ketekunan dalam bekerja misalkan buruh pabrik garmen. (Suekirman,1984)

\section{F. Penelitian Yang Relevan}

Penelitian yang dulu pernah dilakukan adalah Novita sari di dalam penelitiannya yang berjudul "Analisis Faktor-faktor yang Berhubungan dengan Pemilihan Lapangan Pekerjaan di Sektor Informal oleh Perempuan Nikah di Desa Kuntu Kabupaten Kampar". Penelitian yang kedua yaitu skripsi Raika Gustisiyah dengan judul "Analisis Faktor-Faktor Yang Mempengaruhi Motivasi Kerja Penyuluh Perindustrian Pada Kantor Dinas Perindustrian Dan Perdagangan Kota Medan". Penelitian yang ketiga adalah skipsi dari Neng Murialti, dengan karya tulisnya yang berjudul "Faktor-faktor yang Mempengaruhi Buruh Wanita Bekerja Disektor Pertanian dan Disektor Industri Sumatera Barat".

Wantini

66 


\section{G. Kerangka Teori}

Gambar 1: Kerangka konsep

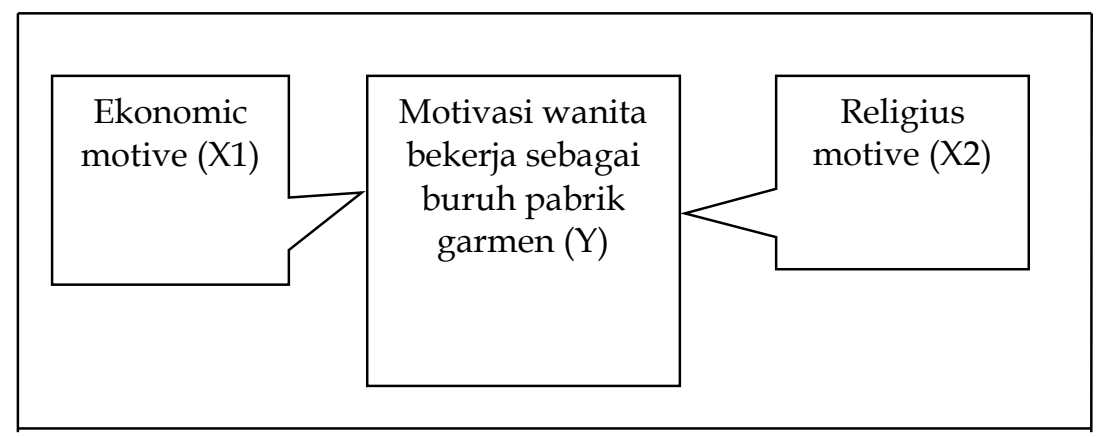

\section{H. Hipotesis}

Hipotesis adalah jawaban sementara terhadap suatu permasalahan yang dihadapi dalam penelitian, dimana jawaban sementara akan diuji lagi kebenarannya. Hipotesis adalah pendapat yang kebenarannya masih rendah atau kadar kebenarannya masih belum meyakinkan.(Sugiono, 2008) Berdasarkan permasalahan, tujuan penelitian, dan landasan teori yang ada di atas maka hipotesis yang dapat diambil adalah sebagai berikut:

a. Motif ekonomi dan motif religius berpengaruh signifikan secara parsial (individu) terhadap motivasi wanita bekerja sebagai buruh pabrik garmen di PT Ameya Living Style Indonesia.

b. Motif ekonomi dan motif religius berpengaruh signifikan secara bersama-sama terhadap motivasi wanita bekerja sebagai buruh pabrik garmen PT Ameya Living Style Indonesia.

\section{Metode Penelitian}

a. Jenis Penelitian

Jenis penelitian ini adalah penelitian lapangan (survey), survey adalah penelitian dengan cara mengambil sampel dari suatu populasi dan menggunakan instrumen atau wawancara untuk mendapatkan tanggapan dari responden yang dijadikan sampel. (Sigit, 1999)

\section{b. Rancangan Penelitian}

Rancangan penelitian yang digunakan adalah dengan menggunakan Cross sectional yaitu dalam penelitian ini pengumpulan datanya dilakukan dengan satu periode tertentu, setiap subyek, studinya hanya satu kali pengamatan selama penelitian, dan dalam pemberian kuesioner hanya satu kali dilakukan. (Supardi, 2005)

\section{c. Subyek Penelitian}

Adapun yang menjadi subyek dalam penelitian ini adalah warga

Faktorfaktor masyarakat di dusun Gupakwarak yang berjumlah 100 orang yaitu wanitawanita yang bekerja sebagai buruh pabrik garmen di PT Ameya Living Style Indonesia.

\section{d. Populasi Dan Sampel}

Populasi adalah wilayah generalisasi yang terdiri atas obyek/subyek yang mempunyai kualitas dan karakteristik tertentu yang diterapkan oleh peneliti untuk dipelajari dan ditarik kesimpulannya. 
Populasi dalam penelitian ini adalah seluruh wanita di dusun Gupakwarak yang bekerja sebagai buruh pabrik, dengan jumlah 100 orang. Sampel adalah sebagian dari populasi yang karakteristiknya ingin diselidiki. (Sugiono, 2008) Sampel dalam penelitian ini adalah 50 orang responden.

\section{e. Variabel Penelitian}

Dalam penelitian ini terdapat dua variabel yaitu :

1. Variabel bebas (independen) merupakan variabel yang mempengaruhi atau menjadi sebab perubahannya atau timbulnya variabel dependen atau terkait. Adapun variabel dalam penelitian ini adalah economic motive (X1) yaitu merupakan suatu faktor yang mempengaruhi motivasi wanita bekerja sebagai buruh pabrik garmen dilihat dari sisi ekonomi, dan religius motive (X2) yaitu merupakan suatu faktor yang mempengaruhi wanita bekerja sebagai buruh pabrik garmen dilihat dari sisi agamanya.

2. Variabel terkait (dependen) merupakan variabel yang dipengaruhi atau yang menjadi akibat karena adanya variabel bebas. Variabel terkait dalam penelitian ini adalah motivasi wanita bekerja sebagai buruh pabrik garmen (Y). Variabel-variabel ini diukur dengan menggunakan skala likert yang memungkinkan responden dapat menjawab pertanyaan dari setiap butir yang dicantumkan.

\section{f. Teknik Pengumpulan Data}

Untuk mencapai tujuan yang diinginkan maka pengumpulan data yang dilakukan yaitu:

1. Pengamatan

Pengamatan ini dilakukan dalam rangka memahami tindakan yang dilakukan wanita-wanita yang bekerja sebagai buruh pabrik garmen.

\section{Kuesioner}

Dalam penelitian ini teknik kuesioner digunakan agar mendapatkan data primer. Data primer adalah sumber data yang diperoleh secara langsung dari sumber asli atau tidak melalui media perantara. (Umar, 2000)

3. Dokumentasi

Dalam penelitian ini teknik dokumentasi digunakan agar mendapatkan data yang sifatnya tertulis, misalnya jumlah penduduk wanita yang bekerja sebagai buruh pabrik garmen.

\section{g. Uji Instrumen}

Adapun instrumen yang akan diuji yaitu:

1. Uji Validitas

Validitas berarti sejauh mana ketepatan dan kecermatan suatu alat ukur dalam melakukan fungsi ukurnya. (Aswar,2008) Validitas suatu item pertanyaan dapat ditentukan dengan melihat tingkat signifikansi pada koefisien korelasi antara skor item pertanyaan dengan skor total pertanyaan jika total signifikansi koefisien korelasi $\leq 0,05$. Maka item pertanyaan tersebut dinyatakan valid. (Sugiono, 2005) Rumus yang digunakan untuk uji validitas ini adalah dengan korelasi Product Moment.

Wantini

2. Uji Reliabilitas 
Uji reliabilitas merupakan cara untuk melihat apakah alat ukur yang berupa kuesioner digunakan secara konsisten atau tidak. Uji reliabilitas dalam penelitian ini menggunakan koefisien alpha (a) dengan kriteria nilai koefisien alpha $\geq 0,60$ maka dianggap reliabel. (Sugiono, 2008)

\section{h. Pengolahan Dan Analisis Data} berikut:

Dalam penelitian ini analisis yang digunakan adalah sebagai

1. Analisis Deskriptif

Analisis ini digunakan untuk menganalisis data dengan cara mendeskripsikan dan menggambarkan data yang telah terkumpul sebagaimana adanya, tanpa bermaksud membuat kesimpulan yang berlaku untuk umum atau generalisasi. (Sugiono, 2008)

2. Analisis Regresi Linier Berganda

Untuk menganalisis permasalahan digunakan alat analisis regresi linier berganda. Analisis berganda digunakan untuk mengetahui pengaruh antar suatu variabel terkait (dependen) dan variabel bebas (independen).

3. Uji Hipotesis

Uji hipotesis yang pertama dengan menggunakan uji $t$ yaitu untuk menguji tingkat signifikasi pengaruh variabel dependen dan independen secara parsial. Untuk uji hipotesis yang kedua dengan menggunakan uji $\mathrm{F}$ yaitu untuk menguji tingkat signifikansi pengaruh variabel dependen dan independen secara serentak atau bersama-sama.

\section{J. Hasil Analisis Dan Pembahasan}

\section{a. Letak Geografis}

Batasan geografis dusun Gupakwarak adalah sebagai berikut: Sebelah utara berbatasan dengan dusun Dadabong, Sebelah timur berbatasan dengan dusun Bungsing, Sebelah barat berbatasan dengan dusun Kabrokan Wetan, Sebelah selatan berbatsan dengan dusun Beji. Letak dusun Gupakwarak termasuk strategis karena termasuk jalur kabupaten, tidak salah para investor memilih dusun ini untuk didirikan ndustri.

\section{b. Keadaan Masyarakat Di Dusun Gupakwarak}

Jumlah penduduk di dusun Gupakwarak adalah sekitar \pm 776 dengan jumlah penduduk laki-laki sebanyak 382 orang dan jumlah penduduk perempuan sebanyak 394 orang. Adapun yang bekerja sebagai buruh sebanyak 177 orang, wiraswasta sebanyak 245 orang, ibu rumah tangga sebanyak 8 orang, buruh tani sebanyak 40 orang sisanya masih pelajar dan belum sekolah atau sekitar 306 orang.

Faktorfaktor

\section{c. Uji Instrumen}

Adapun hasil uji instrument adalah sebagai berikut:

1. Uji Validitas

\begin{tabular}{|l|l|l|l|l|}
\hline Variabel & Item & R hitung & signifikasi & keterangan \\
\hline Motif ekonomi & $\mathrm{X} 11$ & .542 & .002 & Valid \\
\hline
\end{tabular}




\begin{tabular}{|l|l|l|l|l|}
\hline & X12 & .719 & .000 & Valid \\
& X13 & .798 & .000 & Valid \\
& X14 & .707 & .000 & Valid \\
& X15 & .606 & .000 & Valid \\
& X16 & .644 & .000 & Valid \\
& X17 & .668 & .000 & Valid \\
& X18 & .536 & .002 & Valid \\
& X19 & .544 & .002 & Valid \\
& X110 & .663 & .000 & Valid \\
& & & & \\
\hline Motif religius & X21 & .916 & .000 & Valid \\
& X22 & .749 & .000 & Valid \\
& X23 & .882 & .000 & Valid \\
& X24 & .633 & .000 & Valid \\
& X25 & .806 & .000 & Valid \\
& X26 & .826 & .000 & Valid \\
& X27 & .630 & .000 & Valid \\
& X28 & .654 & .000 & Valid \\
& X29 & .763 & .000 & Valid \\
& X210 & .644 & .000 & Valid \\
& Y1 & .763 & .000 & Valid \\
\hline $\begin{array}{l}\text { Motivasi } \\
\text { wanita bekerja } \\
\text { sebgai buruh } \\
\text { pabrik garmen }\end{array}$ & Y2 & .761 & .000 & Valid \\
& Y3 & .644 & .000 & Valid \\
& Y5 & .455 & .000 & Valid \\
& & & .014 & Valid \\
\hline
\end{tabular}

Berdasarkan tabel hasil uji validitas variabel-variabel penelitian diatas dapat dilihat bahwa semua tingkat signifikansi koefisien korelasi dari item pertanyaan mempunyai nilai lebih kecil dari 0,05 sehingga semua item pertanyaan pada variabel penelitian adalah valid pada derajat $5 \%$ dan dapat digunakan untuk mengukur masalah yang diteliti.

2. Uji Reliabilitas

Hasil uji reliabilitas adalah sebagai berikut:

\begin{tabular}{|l|l|l|}
\hline Variabel & $\begin{array}{l}\text { Alpha } \\
\text { cronbach }\end{array}$ & Keterangan \\
\hline Motif ekonomi & 0,8390 & Reliable \\
\hline Motif religius & 0,8957 & Reliable \\
\hline $\begin{array}{l}\text { Motivasi wanita } \\
\text { bekerja sebagai } \\
\text { buruh pabrik }\end{array}$ & 0,8118 & Reliable \\
\hline
\end{tabular}

Berdasarkan tabel diatas dapat diperoleh hasil alpha cronbach lebih dari 0,60. Hal ini menunjukkan bahwa hasil uji reliabilitasnya adalah semua variabelnya dapat dikatakan handal sehingga dapat dipergunakan 


\section{Analisis Diskriptif}

\subsection{Karakteristik Responden}

Responden yang diambil dalam penelitian ini berjumlah 50 responden warga di dusun Gupakwarak yang menjadi buruh pabrik garmen di PT Ameya Living Style Indonesia. Untuk memberikan gambaran umum responden dalam penelitian ini maka disajikan diskripsi responden yang meliputi usia, agama, pendidikan terakhir, lama bekerja, dan penghasilan perbulan.

Tabel 1.1 Karakteristik Responden Berdasarkan Usia

\begin{tabular}{|l|l|l|l|}
\hline $\begin{array}{l}\text { No } \\
.\end{array}$ & Uraian & Jumlah & Persentase \\
\hline 1. & $<20$ tahun & 2 & $4 \%$ \\
\hline 2. & $20-30$ tahun & 42 & $84 \%$ \\
\hline 3. & $30-40$ tahun & 5 & $10 \%$ \\
\hline 4. & $>40$ tahun & 1 & $2 \%$ \\
\hline & & 50 & $100 \%$ \\
\hline
\end{tabular}

Hasil penelitian menunjukkan bahwa sebagian besar responden dalam penelitian ini merupakan pekerja yang masih berusia muda dan produktif sehingga dalam bekerja masih mempunyai fisik yang kuat, dan semangat yang tinggi untuk bekerja.

Tabel 1.2 Karakteristik Responden Berdasarkan Agama

\begin{tabular}{|l|l|l|l|}
\hline No. & Uraian & Jumlah & Persentase \\
\hline 1. & Islam & 50 & $100 \%$ \\
\hline 2. & Non islam & 0 & $0 \%$ \\
\hline & & 50 & $100 \%$ \\
\hline
\end{tabular}

Dari data hasil penelitian di atas tampak bahwa sebanyak 50 orang atau $100 \%$ responden beragama islam. Hal ini menunjukkan bahwa responden yang bekerja sebagai buruh pabrik adalah masyarakat muslim.

Tabel 1.3 Karakteristik Responden Berdasarkan Tingkat Pendidikan

Faktorfaktor

\begin{tabular}{|l|l|l|l|}
\hline No. & Uraian & Jumlah & Persentase \\
\hline 1. & SD & 2 & $4 \%$ \\
\hline 2. & SMP & 42 & $84 \%$ \\
\hline 3. & SMA & 5 & $10 \%$ \\
\hline 4. & Akademi, Diploma, S1 & 1 & $2 \%$ \\
\hline & & 50 & $100 \%$ \\
\hline
\end{tabular}

Hasil penelitian menunjukkan bahwa sebagian besar responden berpendidikan terakhir SMP yaitu sebanyak 43 orang.

Tabel 1.4 Karakteristik Responden Berdasarkan Lama Bekerja

\begin{tabular}{|l|l|l|l|}
\hline No. & Uraian & Jumlah & Persentase \\
\hline 1. & $<1$ tahun & 10 & $20 \%$ \\
\hline 2. & $1-5$ tahun & 38 & $76 \%$ \\
\hline 3. & $6-10$ tahun & 2 & $4 \%$ \\
\hline 4. & $11-15$ tahun & 0 & $0 \%$ \\
\hline & & 50 & $100 \%$ \\
\hline
\end{tabular}

Dari data hasil penelitian di atas menunjukkan bahwa sebagian besar responden bekerja selama 1 sampai dengan 5 tahun, sehingga semakin lama bekerja pengalamannya akan semakin bertambah dan motivasi untuk bekerja lebih tinggi. 
Tabel 1.5 Karakteristik Responden Berdasarkan Penghasilan Perbulan

\begin{tabular}{|c|c|c|c|}
\hline No. & Uraian & Jumlah & Persentase \\
\hline 1. & $<\operatorname{Rp} 500.000$ & 1 & $2 \%$ \\
\hline 2. & $\operatorname{Rp} 500.000-\operatorname{Rp} 1000.000$ & 42 & $84 \%$ \\
\hline 3. & $\operatorname{Rp} 1.000 .000-\operatorname{Rp} 1.500 .000$ & 7 & $14 \%$ \\
\hline 4. & $>\operatorname{Rp} 2.000 .000$ & 0 & $0 \%$ \\
\hline & & 50 & $100 \%$ \\
\hline
\end{tabular}

Dari hasil penelitian seperti pada tabel diatas menunjukkan bahwa sebagian besar responden berpenghasilan Rp 500.000 - Rp 1.000.000

\section{Persepsi Responden Berdasarkan Variabel Penelitian}

Adapun hasil penelitiannya adalah sebagai berikut:

\subsection{Variabel Motif Ekonomi}

\begin{tabular}{|l|l|l|l|}
\hline Interval & Persepsi responden & Jumlah & Persentase \\
\hline $1,00-1,79$ & Sangat tidak setuju & 1 & $2 \%$ \\
\hline $1,80-2,59$ & Tidak Setuju & 2 & $4 \%$ \\
\hline $2,60-3,39$ & Netral & 18 & $36 \%$ \\
\hline $3,40-4,19$ & Setuju & 26 & $52 \%$ \\
\hline $4,20-5,00$ & Sangat setuju & 3 & $6 \%$ \\
\hline & & 50 & $100 \%$ \\
\hline
\end{tabular}

Berdasarkan hasil penelitian di atas menunjukkan bahwa sebagian besar responden berpersepsi setuju terhadap variabel motif ekonomi dan responden memiliki dorongan yang kuat dalam bekerja berdasarkan keinginan untuk memenuhi kebutuhan hidup di dunia.

\subsection{Variabel Motif Religius}

\begin{tabular}{|l|l|l|l|}
\hline Interval & Persepsi responden & Jumlah & Persentase \\
\hline $1,00-1,79$ & Sangat tidak setuju & 0 & $0 \%$ \\
\hline $1,80-2,59$ & Tidak Setuju & 1 & $2 \%$ \\
\hline $2,60-3,39$ & Netral & 7 & $14 \%$ \\
\hline $3,40-4,19$ & Setuju & 29 & $58 \%$ \\
\hline $4,20-5,00$ & Sangat setuju & 13 & $26 \%$ \\
\hline & & 50 & $100 \%$ \\
\hline
\end{tabular}

Berdasarkan tabel hasil penelitian diatas menunjukkan bahwa sebagian besar responden berpersepsi setuju terhadap variabel motif religius dan responden memiliki dorongan yang kuat dalam bekerja berdasarkan keinginan untuk memenuhi kebutuhan rohani atau akhirat.

2.3 Variabel Motivasi Wanita Bekerja Sebagai Buruh Pabrik

\begin{tabular}{|l|l|l|l|}
\hline Interval & Persepsi responden & Jumlah & Persentase \\
\hline $1,00-1,79$ & Sangat tidak setuju & 1 & $2 \%$ \\
\hline $1,80-2,59$ & Tidak Setuju & 2 & $4 \%$ \\
\hline $2,60-3,39$ & Netral & 7 & $14 \%$ \\
\hline $3,40-4,19$ & Setuju & 30 & $60 \%$ \\
\hline $4,20-5,00$ & Sangat setuju & 10 & $20 \%$ \\
\hline & & 50 & $100 \%$ \\
\hline
\end{tabular}

Wantini

Berdasarkan tabel diatas menunjukan bahwa sebagian besar responden mempersepsikan setuju terhadap variabel moitivasi wanita bekerja sebagai buruh pabrik dan responden memiliki dorongan yang kuat untuk melakukan suatu kegiatan atau pekerjaan. 


\section{Analisis Kuantitatif}

3.1 Analisis regresi linier berganda

Tabel 3.1 : Hasil analisis regresi linier berganda adalah sebagai berikut :

\begin{tabular}{|c|l|}
\hline Variabel & Koefisien regresi \\
\hline Konstanta & 0,956 \\
Motif ekonomi & 0,463 \\
Motif religius & 0,284 \\
\hline
\end{tabular}

$\mathrm{R}=0,749 \quad \mathrm{R}^{2}=0,561$

Adj $R^{2}=0,550$

$\mathrm{F}$ hitung $=26,613 \quad$ Signifikan $\mathrm{F}=0,0000$

Berdasarkan data diatas dapat diperoleh persamaan regresi linier berganda hasil estimasi adalah sebagai berikut:

$$
\mathrm{Y}=0,956+0,463 \mathrm{X} 1+0,284 \mathrm{X} 2
$$

Dengan persamaan tersebut dapat dijabarkan sebagai berikut:

a. Nilai konstanta yaitu 0,956 (positif).

b. Koefisien regresi variabel motif ekonomi $(X 1)=0,463$

Variabel motif ekonomi cenderung mempunyai pengaruh yang searah dengan variabel motivasi wanita bekerja sebagai buruh pabrik. Semakin tinggi motif ekonomi maka akan semakin tinggi motivasinya untuk bekerja, demikian pula sebaliknya semakin rendah motif ekonomi semakin rendah pula motivasinya untuk bekerja.

c. Koefisien regresi variabel motif religius $(X 2)=0,284$

Variabel motif religius mempunyai pengaruh yang searah dengan variabel motivasi wanita bekerja sebagai buruh pabrik. Semakin tinggi motif religius maka akan semakin tinggi pula motivasinya untuk bekerja, demikian pula sebaliknya semakin rendah motif religius semakin rendah pula motivasinya untuk bekerja.

\section{Uji Hipotesis}

Uji hipotesis yang pertama menggunakan uji $t$ yaitu untuk mengetahui tingkat signifikansi pengaruh secara parsial (individu) variabel motif ekonomi dan motif religius terhadap variabel motivasi wanita bekerja sebagai buruh pabrik. Pengujian dengan menggunakan uji $t$ adalah dengan membandingkan probabilitas kesalahan $t$ hitung dengan signifikansi yang dapat ditolelir $(\alpha=5 \%)$. Hasil uji hipotesis dengan menggunakan uji $\mathrm{t}$

\begin{tabular}{|l|l|l|l|l|}
\hline Variabel & T hitung & Probabilitas & Keterangan & Arah \\
\hline $\begin{array}{l}\text { Motif } \\
\text { ekonomi }\end{array}$ & 8,495 & 0,000 & Signifikan & Positif \\
\hline Motif religius & 7,527 & 0,000 & Signifikan & Positif \\
\hline
\end{tabular}

Faktorfaktor

Dari tabel hasil uji hipotesis diatas dapat dilihat hasil perhitungan diperoleh untuk:

a. Variabel motif ekonomi mempunyai t hitung sebesar 8, 495 dengan tingkat signifikansi sebesar 0,000 lebih kecil dari a $(0,000<0,050)$. Ini berarti motif ekonomi secara parsial berpengaruh signifikan terhadap variabel motivasi wanita bekerja sebagai buruh pabrik.

b. Variabel motif religius mempunyai $\mathrm{t}$ hitung sebesar 7,527 dengan tingkat signifikansi 0,000 yang lebih kecil dari a $(0,000<0,050)$. Ini 
berarti bahwa motif religius secara parsial berpengaruh signifikan terhadap variabel motivasi wanita bekerja sebagai buruh pabrik. Dengan demikian hipotesis yang menyatakan bahwa motif ekonomi dan motif religius secara parsial berpengaruh signifikan terhadap variabel motivasi wanita bekerja sebagai buruh pabrik garmen di PT Ameya Living Style di dukung.

Uji hipotesis yang kedua dengan menggunakan uji $F$ untuk mengetahui pengaruh tingkat signifikasi pengaruh secara bersama-sama variabel motif ekonomi dengan motif religius terhadap variabel motivasi wanita bekerja sebagi buruh pabrik. Pengujian melalui $\mathrm{F}$ hitung adalah dengan membandingkan probalitas kesalahan $\mathrm{F}$ hitung dengan signifikasi yang dapat ditolirir $(\alpha=5 \%)$.

Berdasarkan tabel 3.1 dapat diperoleh hasil perhitungan $\mathrm{F}$ hitung sebesar 26,613 dengan tingkat signifikasi 0,000 yang lebih kecil dari a $(0,000$ $<0,050)$ atau Ho tidak diterima dan Ha diterima. Ini berarti bahwa motif ekonomi dan motif religius berpengaruh signifikan terhadap variabel motivasi wanita bekerja sebagai buruh pabrik. Dengan demikian hipotesis yang menyatakan bahwa motif ekonomi dan motif religius secara bersamasama berpengaruh signifikan terhadap motivasi wanita bekerja sebagai buruh pabrik garmen di PT Ameya Living Style diterima. Dari table 3.1 juga menunjukan bahwa nilai koefisien determinasi $\left(R^{2}\right)$ adalah sebesar 0,561 artinya pengaruh motif ekonomi dan motif religius terhadap motivasi wanita bekerja sebagai buruh pabrik $56,1 \%$ sedangkan sisanya sebesar $43,9 \%$ dipengaruhi variabel lain diluar penelitian ini.

\section{K. Penutup}

a. Kesimpulan

Berdasarkan hasil penelitian yang telah dilaksanakan maka dapat diambil kesimpulan bahwa faktor-faktor yang mempengaruhi motivasi wanita bekerja sebagai buruh pabrik garmen di PT Ameya Living Style adalah faktor ekonomi, diantara faktor ekonomi yaitu keinginan untuk memenuhi kebutuhan lahir, tempat bekerja lebih dekat sehingga dapat menghemat biaya transportasi, keinginan untuk mendapatkan pengalaman, keinginan untuk meningkatkan status sosial, dan dorongan untuk mendapatkan penghargaan. Adapun faktor yang selanjutnya yaitu faktor agama atau religius, diantara faktor religius adalah keinginan untuk mendapatkan berkah pahala dari Allah karena bekerja merupakan suatu ibadah, bisa bekerja karena mendapatkan izin dari suami, teman bekerja mayoritas adalah wanita.

\section{b. Saran}

Untuk mengakhiri tulisan ini ada beberapa saran yang akan diberikan kepada semua pihak yang terkait:

1. Warga masyarakat di dusun Gupakwarak

a. Selalu berusaha untuk bekerja keras untuk memenuhi kebutuhan lahir dan batin

b. Tingkatkan terus kebersamaan dalam menjunjung tinggi nilai-nilai agama walaupun lelah seharian dalam bekerja 
2. Pemimpin perusahaan PT Ameya Living Style Indonesia

Terus memotivasi para karyawan agar tetap semangat dalam bekerja untuk menapai tujuan perusahaan.

3. Akademisi

Penelitian ini dapat dijadikan sebagai bahan informasi bagi peneliti yang berminat tentang motivasi wanita bekerja khususnya bekerja sebagai buruh industri

Faktor-

faktor

75 


\section{DAFTAR PUSTAKA}

Arikunto, Suharsimi, 2006, Prosedur Penelitian suatu Pendekatan Praktik, Jakarta, Rineka Cipta

Aswar, Syarifudin, 2008, Reliabilitas dan Validitas, Yogyakarta: Pustaka Pelajar, Edisi.3, Cetakan ke 8

Duane, Schultz, 1991, Psikologi Pertumbuhan Model-model Kepribadian Sehat, Yogyakarta: Kanisius

Elfindri, Nasri B. 2004, Ekonomi Ketenagakerjaan, Padang: Universitas Andalas

Frank G, Goble, 1987, Mazhab Ketiga Psikologi Humanistik Abraham Maslow, Yogyakarta: Kanisius

Husain, Umar, 2000, Riset Sumber Daya Manusia dalam Organisasi, Jakarta: PT. Gramedia Pustaka Utama

Koeswara, E., 1991, Teori-teori Kepribadian, Bandung: PT Eresco

Kreitner, Robert, \& Kinicki, Angelo, 2003, Perilaku Organisasi, Jakarta: Salemba Empat

Mugnesiah, M. Sugiah, 1986, Kepemimpinan Wanita Dalam Pembanguan Desa, Bogor: Fakultas pasca sarjana, IPB

Munandar, SC Utami, 1985, Emansipasi dan Peran Ganda Wanita Indonesia, Jakarta: UII Press

Musafa Addarinny, 2013, Bolehkah Wanita Bekerja, http://www.konsultasisyariah.com, diakses tanggal 2 juli 2013, jam 14.05

Nurgiantoro, Burhan, 2002, Statistik Terapan untuk Penelitian Ilmu-ilmu Sosial, Yogyakarta: Gadjah Mada University

Robbins, Stephen P. 2002, Prinsip-prinsip Organisasi, Jakarta: Salemba Humanika, edisi ke lima

Sigit, Suhardi, 1999, Metodologi Penelitian, Yogyakarta: BPEF

Singarimbun, Masri, \& Safri Sairih, 1995, Liku-liku Kehidupan Buruh Perempuan, Yogyakarta: Yayasan Annisa swati

Suekirman, 1984, Wanita Kerja dan Keadaan Gizi Anak, Jakarta: YIIS

Sugiono, 2008, Metode Penelitian Bisnis, Bandung: CV Alfabetta 2005, Metode Penelitian Bisnis, Bandung: CV Alfabeta

Supardi, 2005, Metode Penelitian Ekonomi dan Bisnis, Yogyakarta: UII press

Wantini 